\title{
MIGRANT ENTREPRENEURSHIP IN EUROPE: CHALLENGES AND OPPORTUNITIES
}

\author{
Vida Davidavičiené $\dot{e}^{1}$, Ingrida Lolat ${ }^{2}$ \\ ${ }^{I}$ Department of Business Technologies, Faculty of Business Management, \\ Vilnius Gediminas Technical University, Sauletekio al. 11, 10223 Vilnius, Lithuania \\ ${ }^{2}$ Department of International Economics and Business Management, Faculty of Economics and Management, \\ Otto-von-Guericke-University, Universitätsplatz 2, Vilfredo Pareto Building (G22), 39106 Magdeburg, Germany \\ E-mails: ${ }^{1}$ vida.davidaviciene@vgtu.lt; ${ }^{2}$ ingridalolat@gmail.com (corresponding author)
}

\begin{abstract}
In the last decades a handful of scientist investigated the topic of migrant entrepreneurship in Europe. Therefore historical background, reasons of migrant self-employment or the impacts for host countries, home countries and at the European level could be identified. Still nowadays, there exist no corporate understanding of the term and the limited statistics do not use common definitions or measurements. The purpose of this article identify migrant self-employment in Europe challenges and identify migrant friendly EU countries in terms of e-services for new business establishment. Consequently existing literature and institutions were taken into consideration, analysis of statistics and countries e-government development were analysed.
\end{abstract}

Keywords: migrant entrepreneurship, self-employment, migrant employment in Europe, highly-qualified EU nationals, migrant business, e-government services.

JEL Classification: J61; L86; M13; O52; O57.

\section{Introduction}

In 1992, with the Contract of Maastricht the European Union was established and focuses on the target: creation of a strong politico-economic union in Europe. The treaty was designed to enhance European political and economic integration by creating a single currency, a unified foreign and security policy, common citizenship rights and by advancing cooperation in the areas of immigration, asylum, and judicial affairs. Europe generates its economic power through e.g. fiscal support in economic weak areas and care of migrant entrepreneurship which lead to know-how, culture and product transfer (Baycan-Levent, Nijkamp 2005).

The following paper will not point out the importance of migrant entrepreneurs in European countries, their advantages and disadvantages of receiving and sending economies or the overall welfare also it will not summarize the historical background of implementing migrants' start-ups in European countries because these topics are more or less explored by previous literature. Furthermore, it will review existing literature with the specific purpose of taking a deeper look into migrant entrepreneurship with the focus on material that can help to answer the following question: Which European country is the migrant-friendliest one according establishing of enterprises by migrant self-employed people?
Aim of this article identify migrant selfemployment in Europe challenges and identify migrant friendly EU countries in terms of e-services for new business establishment. The literature review should confirm or discourage for a further article which analysis specific determinants that allow conclusions for interested people in selfemployment in host countries and for political support decisions according migrant entrepreneurship in specific countries and generally in Europe. Methods used are scientific research, analysis and comparison, and statistical and secondary data analysis.

According the lack of high-quality nationals many European countries reduced the barriers for migrant self-employment with the purpose to get skilled people and sustainable business ideas in their countries. Most "Organization for Economic Cooperation and Development countries" have implemented policies to attract talented foreigners with entrepreneurial ideas and skills, and continued to promote immigrant entrepreneurship because of recognition of the value and innovation power created by migrants (OECD 2006). Several scientists analyzed migrant entrepreneurship in their specific countries or in general in Europe. Still, migrant entrepreneurship is a less discovered topic and equality in surveys, data and conceptions is not given which leads to difficulties to compare mi-

(C) 2016 The Authors. Published by VGTU Press. This is an open-access article distributed under the terms of the Creative Commons Attribution License (CC-BY 4.0), which permits unrestricted use, distribution, and reproduction in any medium, provided the original author and source are credited. 
grant entrepreneurs at the governmental and European level.

While immigrants tend to set up businesses at a higher rate than their native-born peers, they face greater obstacles mostly due to limited social capital, language barriers, access to financial institutions, and lack in understanding market know-how. These difficulties may prevent migrant entrepreneurs from releasing their full potential to promote the "socioeconomic revitalization, growth, and competitiveness" of host countries (Desiderio 2014). But previous literature shows that through migrant entrepreneurs home countries, host countries and the whole European Union profit.

Therefore, this article is separated into: clearing of the specialist terms of "entrepreneurship" and "migrant entrepreneurship" which are used and interpreted in different ways by researchers. Section 2 investigates former literature which covers migrant entrepreneurship in Europe. Firstly, an analysis of literature addressing general European context will be reviewed and secondly, an analysis of migrant entrepreneurship in five specific European countries: Greece, the United Kingdom, the Netherlands, Belgium, and Switzerland will be examined. The involvement of institutions of $\mathrm{Eu}-$ ropean Commission is suggested in following section. The paper will end with conclusions, limitations of this article and suggestions for future works.

\section{Clearing of the definitions}

As with entrepreneurship that is a multidimensional concept, the definition depends largely on the focus of the research undertaken (Verheul et al. 2001). Entrepreneurship has been correctly characterized as one of the most intriguing but equally elusive concepts in economics by Baumol (1968). One possible reason for the variety of concepts is the interdisciplinary nature of the topic, involving scholars from the fields of: economics, business strategy, organizational behavior, sociology, and psychology. The different understandings are often resulted through competing strands and research traditions. For instance, scholars of business strategy and management typically apply behavioral and process perspective because of their interest in how to act entrepreneurially. Economists apply entrepreneurship as a particular function, which it fulfills in order to enhance the operations of the overall system. This certain standpoints of stakeholders were explained by Peneder (2009). In his working paper "The meaning of entrepreneurship: a modular concept" he summarized different standpoints of entrepreneurship into behavioral, occupational and functional dimensions of entrepreneurship.

Besides this dimensional separation "entrepreneurship" is understood as the process of designing a new business. Entrepreneurship in the classical sense refers to the combining of resources in novel ways so as to create something of value (Aldrich, Waldinger 1990). Self-employment normally involves setting up a new business or buying an existing business. At the same time it is a source of sustainable socio-economic development. Gartner (1990) concluded from his Delphi survey of 1987 that the nature of entrepreneurship can be characterized by eight themes which are: the entrepreneur, innovation, organization creation, creating value, profit or nonprofit, growth, uniqueness and owner-manager. The entrepreneurial opportunities defined as "situations in which new goods, services, raw materials, markets and organizing methods can be introduced through the formation of new means, ends, or means-ends relationships" by Eckhardt and Shane (2003a).

Some authors lay specific emphasis upon the Schumpeterian idea of innovative entrepreneurship which caused considerable confusion by restricting entrepreneurship to an elite group of innovative business. Examples for this position are Venkataraman (1997) or Rumelt (1987). Other authors concentrate their theories of entrepreneurship on a person-centric perspective, in which entrepreneurship depends on stable, enduring differences among people rather than differences in the information about the presence of opportunities (Eckhardt, Shane 2003b).

Considering the diversity of approaches to entrepreneurship Schmiemann's (2012) definition is seen as sufficient and as most convenient for the purpose of this article. His entrepreneurial characterization is the following one: "Entrepreneurship is the mindset and process to create and develop economic activity by blending risk-taking, creativity and/or innovation with sound management, within a new or an existing organization." To understand the mindset of this article best, the part "an existing organization" should be ignored and "economic activity" is defined here as the creation of value (an innovation and/or a new organization). Therefore, the created definition to fit the mentality of this article is: Entrepreneurship is the mindset and process to create value (an innovation and/or a new organization) and develop economic activity within a new organization.

In 1986 Aldrich and Zimmer already said that the formation of new organization can be conceptualized as a "function of opportunity structures 
and motivated entrepreneurs with access to resources" (Aldrich, Zimmer 1986). For the goal of this article it is sufficient to define entrepreneurs as owner-managers running enterprises that have not to be exclusively limited to innovative ideas, meaning that duplications of existing businesses are included too. By new organizations, those meant are founded dependently and independently from novelty.

General expressions like migrant, immigrant, ethnic (minority), foreign or refugee entrepreneurship seem to cover the fuzzy topic of people businesses that are not origins from the country where the organizations are founded. It includes foreign and foreign-born people, who are individuals without host country citizenship and already living in the country. The latter phenomenon distinguishes itself from indigenous entrepreneurship through its orientation on migrant products, on migrant market customers, or on indigenous migrant business strategies. Migrant entrepreneurship is also generally regarded as an important self-organizing principle through which migrant minorities are able to improve their weak socio-economic position (BaycanLevent et al. 2003). Chaganti and Greene (2002) make the following distinction into three groups of migrant businessmen and businesswomen:

i) Immigrant entrepreneurs are individuals who, as recent arrivals in the country, have had to start a business as a means of economic survival (Butler, Greene, 1997). Immigrants are defined as persons who have been born abroad, irrespective of their nationality and whether they are considered ethnic minorities or not in the countries involved. "Immigrants" also include the offspring of immigrants, the second generation or the native born children of the first generation. In practice, the policy measures and support schemes rarely distinguish between generations of immigrants.

ii) Migrant entrepreneurs are united by a set of socio cultural connections and regular patterns of interaction among people sharing a common national background or migration experiences (Waldinger et al. 1990).

iii)(Ethnic) minority entrepreneurs are business owners who are not of the majority population (US Department of Commerce 1997).

A further term - refugee entrepreneurs was found in the literature and is added here due to completeness. iv) Refugee entrepreneurs are a special type of immigrants (Wauters, Lambrecht 2008).

For the purpose of this article a deep separation of these clusters is not necessary and therefore all this four varieties are summarized under migrant entrepreneurship. A further reason is that in most Journal Articles no separation is undertaken and migrant entrepreneurship is the established common term.

\section{Migrant entrepreneurship in Europe}

The studies focused on migrant entrepreneurship started in the United States (Light 1972). Ward and Jenkis (1984) covered the further development of the studies of migrant entrepreneurship in Western Europe, Simon (1993) investigated studies in United Kingdom and France. The main conclusion of these surveys is that migrants have a big share in small and medium enterprises. The legal and administrative barriers for migration within the Union have been reduced in the wake of the Single Market Program. The main feature of economic restructuring in the last decades has been a marked shift from employment in large firms to selfemployment in small firms. In general, immigrants are more likely to be self-employed than similarly skilled native-born workers (Verheul et al. 2001). Since 1980s, self-employment among migrant groups has increased significantly in Europe. Baycan-Levent and Nijkamp (2007) could identify four migrants flows of entry: labor migration, family reunification, undocumented workers (illegal immigrants), and asylum seekers (Stalker 2002). With the rising number of migrant entrepreneurs, the amount of literature by scholars and governmental institutions like European Commission or data published by e.g. private surveys increased too.

The importance of migrant entrepreneurship for Europe is recognized by scholars and policy makers. A remarkable literature covers the issue. Kloosterman (2010) develops an innovative analytical framework "Model of the Opportunity Structure" for the analysis of migrant entrepreneurship. $\mathrm{He}$ enhances the relation between opportunities and the access to markets. Due to market opening for new businesses, entrepreneurs have a sufficient demand for a certain bundle of products. His model is bipolar separated into differences in entry barriers (in terms of human capital) and into dynamics (growing or stagnating). The relation of opportunities, resources and outcome of immigrant entrepreneurship is presented that dependent from business and market the most efficient conclusions can be 

forecasted. Baycan-Levent and Nijkamp (2007) are writing that "migration provides many benefits and contributes to economic growth and the creation of new jobs." These opportunities are strongly associated with the willingness to take up chances across regions and the supply of jobs regulates the flow of people seeking work (Baycan-Levent, Nijkamp 2007). Since entrepreneurship is one of the frequently used ways to escape unemployment in a host country, it is expected that migrants will attempt to choose self-employment.

Baycan-Levent and Nijkamp (2005) wrote in their paper that in the last decades migrant enterprises have become more embedded in the European urban economy and therefore the largest cities in Europe become dynamic multicultural economies. These ethnic economies lead to social and economic change in European cities. These changes are characterized by the presence of immigrants, the challenge of a multicultural society, and new forms of integration between foreigners and local populations (Baycan-Levent, Nijkamp 2005). The insertion of immigrants in work raise, on the one hand, problems of the expansion of informal activities (Mingione 2002), and on the other hand, opportunities for cities due to revitalizing formerly derelict shopping streets, introducing new products and new marketing strategies (Masurel et al. 2004), opening up trade links between far away areas, fostering the emergence of new spatial forms of social cohesion (Kloosterman et al. 2002; Quassoli 2002). As the short summary shows, the aim of Baycan-Levents' and Nijkamps' paper is to investigate the forms of migrant entrepreneurship and to interpret the differences in the social integration in European cities. They analyzed existing literature of findings in the literature that addresses the migrant entrepreneurship experiences of different European countries. Therefore, historical backgrounds of European countries with first discoveries of migrants and their features are shown. After a comparative evaluation they identified the European models of migrant entrepreneurship and pointed out the determinants of migrant entrepreneurship in Europe which can partially explained the country-specific developments according integration of migrants (Baycan-Levent, Nijkamp 2005).

In the annual report of OECD in 2006 data is presented that shows the ratio between employment of native and foreign-born people in the years 1995, 2000, 2003 and 2004. The share of foreigners in unemployment is the highest in the Netherlands, but it is also significant in Denmark and Belgium.
As European Commission mentioned in its report "Conclusions and Recommendations of the European Commission's Network "Ethnic Minority Businesses", the problems of analyzing migrant and ethnic minority entrepreneurship are aggravated by the fact that statistical information is "scarce and not fully comparable between countries. There are some key figures for some countries (e.g. selfemployment rates) and estimates but there are no comprehensive official statistics let alone statistics that could be compared internationally." In some cases data are not available because an ethnic differentiation is legally not allowed in the data collection or, more often, the phenomenon of ethnic entrepreneurship it is confused with questions of nationality (e.g. naturalized persons cannot be identified) (European Commission 2008).

The next section addresses the literature review for the specific European countries: Greece, the United Kingdom, the Netherlands, Belgium, and Switzerland. Migrant Entrepreneurship in Greece was investigated by several scientist. For example Hatziprokopiou (2008) covered the difficulties of migrant entrepreneurship according discrimination, unequal access to financial resources or the lack of information transfer. The selfemployed people are concentrated in construction (28 per cent), trade and repair ( 29 per cent) and private households (12 per cent). Hatziprokopiou (2008) emphasizes in his conclusion that "providing all migrants with stability, security and rights is a prerequisite for their effective labor market integration on equal terms with their Greek counterparts." Deeper insights provide Hatziprokopiou and Labrianidis (2010) about the migrant entrepreneurship in Thessaloniki, the second biggest city in Greece. They point out that the accuracy of official data is rather limited and their reliability is problematic. Therefore, they did a research in Thessaloniki and took previous data into consideration.

The aim of the survey was to identify the key characteristics of migrants' entrepreneurship in this specific area. 59 interviews (tracked down through the snowball sampling method) could be made which collected quantitative and qualitative data about "profile and background of business and their owners, their activities, finances, employees and clientele, reasons for starting up and perceptions about progress, problems and prospects." Language barriers tried to be reduced by translators and face-to-face interviews (Hatziprokopiou, Labrianidis 2010). The motivation of migrant entrepreneurs in Greece was investigated by Liargovas and Skandalin (2012). They conducted a survey that provided insights into a variety of critical 

factors which determine the start and existence of ethnic firms.

A further survey could be found in the literature about the United Kingdom by Anyadike-Danes et al. 2007. They had the hypothesis "That nascent entrepreneurs are more likely to be international the better endowed they are with human and social capital and the easier access they have to international markets." They expected "immigrants to have a higher propensity to internationalize, given their foreign strong and weak ties." (AnyadikeDanes et al. 2007).

The content of the literature about the Netherlands includes specific surveys about "economic performance of Turkish migrant entrepreneurs in the highly skilled and high-tech sector in the Netherlands through the use of data envelopment analysis" with its main conclusion that "migrant entrepreneurship is a skill that can be acquired or developed over the years, so that age and experience over a longer period of time are important in increasing efficiency." They conclude that education also plays an important role in increasing the efficiency (Baycan et al. 2008). A year before, the same authors wrote a paper with the purpose to explore and review differences in entrepreneurial attitude between natives and migrants and within migrant groups. The differences are tried to be explained by means of social and cultural indicators.
(Baycan et al. 2007) If there is a difference between first and second generations and the markets in which immigrant entrepreneurs are active. The results showed that the second generation is "more active in mainstream markets and entrepreneurs move from one market to another by the strategic use of ethnicity" (Rusinovic 2008).

Wauters and Lambrecht (2008) analyzed the barriers to refugee entrepreneurship in Belgium and could show that refugees suffer more from barriers than other immigrants. An explanatory model (see Fig. 1) was created which explains the limited number of refugees in Belgium by their difficult access to entrepreneurship, due to a lack of recognized diplomas, skills or start-up capital (access to entrepreneurship) and to rules and legal restrictions such as the professional card (institutional environment) (Wauters, Lambrecht 2008). In the model $\mathrm{R}+$ : a larger barrier for refugees than for immigrants; $\mathrm{R}=1$ refugees and immigrants suffer (almost) equally from this barrier.

Baycan-Levent and Kundak (2009) analyzed motivation and driving forces of Turkish entrepreneurs in two Swiss cities - Geneva and Zurich. Indepth personal interviews were held among Turkish entrepreneurs in the service and catering sectors. The survey confirmed the movement from wage employment to self-employment among Turkish immigrants.

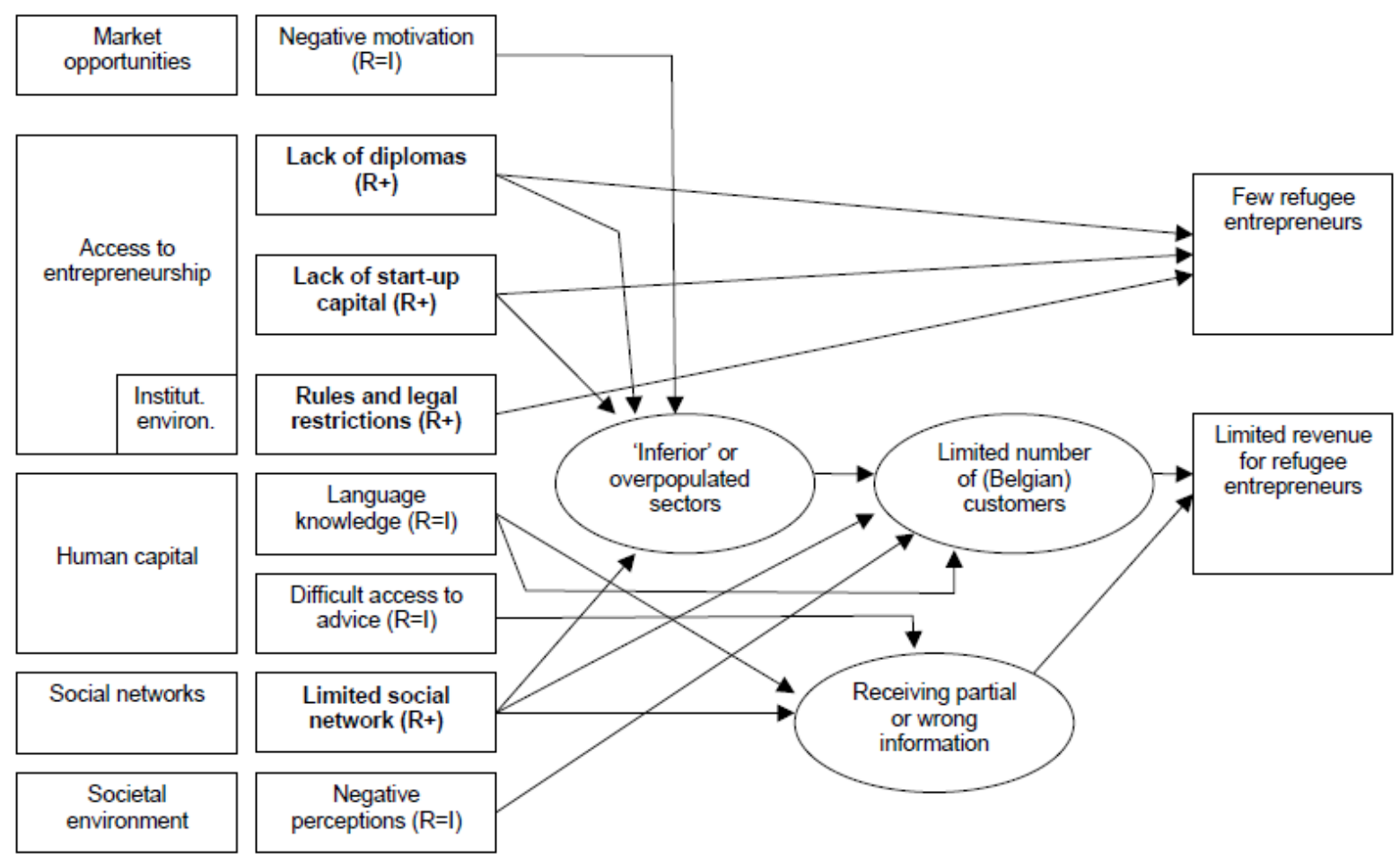

Fig. 1. Explanatory Model for less refugee entrepreneurs in Belgium (Source: Wauters, Lambrecht (2008)) 
Governments in host countries have turned to a mix of targeted and mainstream business support programs. Mainstream support programs are opened for the entire population. Contents of targeted and non-targeted programs are: tailored training services, mentoring and networking initiatives aimed at enhancing immigrants' language proficiency, business skills, and professional contacts, initiatives to improve the creditworthiness of immigrants (and their businesses). These programs should be embedded in a broader policy strategy to create an entrepreneurship-friendly environment (Desiderio 2014).

Baycan-Levent and Nijkamp (2009) evaluated existing quantitative and qualitative data about migrant self-employment in eight European countries (Denmark, Germany, Greece, Italy, the Netherlands, Portugal, Sweden and the United Kingdom) for the purpose of identifying main characteristics of migrant entrepreneurship with their key attributes. Their results are limited to salary comparisons between immigrants and native people and identification of biggest migrant groups in each mentioned country.

The following topics were covered more or less by previous articles and reports:

- Historical background of migrant entrepreneurs in Europe

- Reasons for migrant entrepreneurship

- Requirements for migrant entrepreneurship

- Positive impact of migrant entrepreneurship

- Negative impact of migrant entrepreneurship

- Arguments for migrant entrepreneurship

- Arguments against migrant entrepreneurship

- Trends in migrant entrepreneurship

- Suggestions for politics

- Suggestions for further research in that field.

As the literature review of migrant entrepreneurship generally in Europe and specifically in European countries shows there exists no framework or data which can answer the concerned question. From the conducted surveys in certain regions some conclusions about determinants can be drawn.

\section{Involvement of the European Commission}

As a first idea how to measure entrepreneurship in Europe is done by the European Commission. It publishes statistical books through the institution Eurostat. In 2012, for example, it announced the report called "Entrepreneurship determinants: culture and capabilities" where the results and lessons learnt from work - done by the joint OECD Eurostat Entrepreneurship Indicators Program - are summarized. The program itself aims to develop a comprehensive framework for measurement of entrepreneurial activity. With its help questions like "Why do so many people say they want to start their own business, but so few do it?" or "What are the key factors that shape the decision to become an entrepreneur?" Conceivable factors are regulatory framework, market conditions, entrepreneurial capabilities, culture, access to finance, research and development and technology, etc. (European Commission 2012).

The publication aims to motivate academics and statisticians in their attempts to define internationally comparable indicators for measuring the quality of entrepreneurial education, access to finance or more subjective features like culture and entrepreneurial capabilities.

The European Commission's Network "Ethnic Minority Businesses" is a further institution that analyzes the activities of entrepreneurs in Europe. In Table 1 there are the support activities of certain EU countries summarized that try to support foreign entrepreneurs. As in the table seen many policies are still unclear and data is not available (European Commission 2008).

For the answering of the question if and how to determine features that help to answer the question which one of the European countries has the migrant-friendliest conditions according selfemployment of foreigners requires a deeper investigation of personal, social, cultural and environmental circumstances for foreigners. This data could be found in a team of interested scientist mentioned in previous literature review and the employees of Eurostat and other projects of European Commission like the mentioned network "Ethnic Minority Businesses". From other hand in next section will be analyzed migrant friendly environment in terms of e-government services for self-employment or establishing companies via public e-platforms.

This analysis chosen with the aim to evaluate opportunities and readiness of countries to minimize barriers in establishing business entities when persona are educated and having computer literacy skills. This was based on European Commission's Communique (COM (2010) 743) targeting to improve the public services in order to meet different users' needs and to achieve the maximum social value. 
Table 2. Overview of activities of migrant entrepreneurs and support policies in specific European countries (Source: compiled by the authors)

\begin{tabular}{|c|c|c|c|c|c|c|}
\hline Country & $\begin{array}{l}\text { Size of the } \\
\text { share of mi- } \\
\text { grant/ethnic } \\
\text { businesses }\end{array}$ & $\begin{array}{l}\text { Are mi- } \\
\text { grant/ethnic } \\
\text { Business heter- } \\
\text { ogeneous? }\end{array}$ & $\begin{array}{l}\text { Sectors in which } \\
\text { they operate }\end{array}$ & Special problems? & $\begin{array}{l}\text { Are spe- } \\
\text { cial poli- } \\
\text { cies in } \\
\text { place? }\end{array}$ & $\begin{array}{l}\text { If yes, which } \\
\text { type of policy? }\end{array}$ \\
\hline Bulgaria & No data & - & $\begin{array}{l}\text { Sectors where } \\
\text { low qualification } \\
\text { is sufficient }\end{array}$ & $\begin{array}{l}\text { More than for the } \\
\text { averagebusiness, } \\
\text { e.g. education of } \\
\text { ethnic labour force }\end{array}$ & $\begin{array}{l}\text { Roma in- } \\
\text { clusion } \\
2005-15\end{array}$ & $\begin{array}{l}\text { Mainly infor- } \\
\text { mation, also } \\
\text { grants under } \\
\text { PHARE } \\
\end{array}$ \\
\hline $\begin{array}{l}\text { Czech } \\
\text { Republic }\end{array}$ & $\begin{array}{l}\text { Overpropor- } \\
\text { tioned (Viet- } \\
\text { namese) }\end{array}$ & - & $\begin{array}{l}\text { Retail trade, } \\
\text { wholesale, res- } \\
\text { taurants }\end{array}$ & Bureaucracy & No & - \\
\hline Denmark & - & Very diverse & - & $\begin{array}{l}\text { Lack of knowledge } \\
\text { of business culture, } \\
\text { competition of } \\
\text { EMBs }\end{array}$ & $\begin{array}{l}\text { Regional } \\
\text { initiatives }\end{array}$ & - \\
\hline Italy & $\begin{array}{l}\text { Average or } \\
\text { slightly over- } \\
\text { proportioned }\end{array}$ & - & $\begin{array}{l}\text { Construction, } \\
\text { trade, communi- } \\
\text { cation }\end{array}$ & $\begin{array}{l}\text { Access to finance, } \\
\text { administrative bur- } \\
\text { den }\end{array}$ & $\begin{array}{l}\text { Local ini- } \\
\text { tiatives }\end{array}$ & $\begin{array}{l}\text { Unicredit Agen- } \\
\text { zia TU }\end{array}$ \\
\hline Cyprus & Not clear & $\begin{array}{l}\text { Small family } \\
\text { businesses, } \\
\text { strong reliance } \\
\text { on ethnic group }\end{array}$ & Retail trade & $\begin{array}{l}\text { Clients, finance, } \\
\text { language, skills, } \\
\text { low quality, niche } \\
\text { markets, access }\end{array}$ & No & - \\
\hline Lithuania & No data & - & $\begin{array}{l}\text { catering, trade, } \\
\text { culture }\end{array}$ & N. a. & No & - \\
\hline Austria & $\begin{array}{l}\text { Under propor- } \\
\text { tioned }\end{array}$ & - & $\begin{array}{l}\text { Retail trade, tour- } \\
\text { ism, business } \\
\text { services ( } 2^{\text {nd }} \text { gen- } \\
\text { eration) }\end{array}$ & $\begin{array}{l}\text { Language, admin- } \\
\text { istration, fenced } \\
\text { markets, lack } \\
\text { skilled labour }\end{array}$ & Yes & $\begin{array}{l}\text { Language train- } \\
\text { ing, in formation }\end{array}$ \\
\hline Portugal & $\begin{array}{l}\text { overpropor- } \\
\text { tioned (Chinese } \\
\text { and Americans) }\end{array}$ & - & Retail and food & - & Yes & $\begin{array}{l}\text { Office for immi- } \\
\text { grant entrepre- } \\
\text { neurship support }\end{array}$ \\
\hline Slovenia & $\begin{array}{l}\text { overpropor- } \\
\text { tioned }\end{array}$ & - & $\begin{array}{l}\text { Tourism (Ital- } \\
\text { ians) }\end{array}$ & $\begin{array}{l}\text { More or less like } \\
\text { all SMEs }\end{array}$ & Yes & $\begin{array}{l}\text { EM target in Na- } \\
\text { tional Pro- } \\
\text { gramme for } \\
\text { Promoting En- } \\
\text { trepreneurship }\end{array}$ \\
\hline Sweden & $\begin{array}{l}\text { Slightly over- } \\
\text { proportioned }\end{array}$ & - & $\begin{array}{l}\text { Commerce, ho- } \\
\text { tels, restaurants } \\
\text { (men) }\end{array}$ & - & Yes & $\begin{array}{l}\text { Advise, subsi- } \\
\text { dies, loans }\end{array}$ \\
\hline $\begin{array}{l}\text { United } \\
\text { Kingdom }\end{array}$ & $\begin{array}{l}\text { Proportional } \\
\text { (above average } \\
\text { for Chinese and } \\
\text { Pakistani com- } \\
\text { munities }\end{array}$ & $\begin{array}{l}\text { Increasingly } \\
\text { heterogeneous } \\
\left(2^{\text {nd }} \text { and } 3^{\text {rd }}\right. \\
\text { generations in } \\
\text { more innova- } \\
\text { tive, high value } \\
\text { sectors }\end{array}$ & $\begin{array}{l}\text { Restaurants, re- } \\
\text { tail, wholesale, } \\
\text { transport }\end{array}$ & $\begin{array}{l}\text { Growth, access to } \\
\text { finance }\end{array}$ & $\begin{array}{l}\text { Yes, at } \\
\text { national, } \\
\text { regional } \\
\text { and local } \\
\text { level }\end{array}$ & $\begin{array}{l}\text { Targeted } \\
\text { schemes against } \\
\text { under- } \\
\text { representation. } \\
\text { Consideration of } \\
\text { specific needs in } \\
\text { business support }\end{array}$ \\
\hline Norway & Proportional & Yes & $\begin{array}{l}\text { Catering, trade, } \\
\text { transport, build- } \\
\text { ing }\end{array}$ & Finance, language & Yes & $\begin{array}{l}\text { Credit, guidance, } \\
\text { support }\end{array}$ \\
\hline
\end{tabular}





\section{EU countries e-government services for better migrants involvement}

In order to identify most friendly or open for business establishment EU countries, the idea of analysis of e-government services or public e-services taken. First, the exist indexes, showing countries e-participation level or network readiness level as well as initiatives for migrant involvement like one stop shop project, should be analyzed for identifying most advanced in terms of e-services countries. Countries for analysis will be the same as in previous research presented in Table 1. Taking in mind those methodologies of indexes such peculiarities will be taken in to account:

- e-participation index (EPI) provided by UNPAN (2014) evaluates such aspects as consulting, informing and making decisions in the e-environment as well as getting feedback from citizens. This index shows;

- networked readiness index (NRI) (The Global Information Technology Report 2015 (Dutta et al. 2015)): distributed across the different pillars: Political and regulatory environment; Business and innovation environment; Infrastructure; Affordability; Skills; Individual usage; Business usage; Government usage; Economic impacts; Social impacts (it consist of 53 idexes in 10 categories).

- E-government development index (EGDI) provided by UNPAN (2014) consist of Online Service Index, Telecommunication Infrastructure Index, Human Capital Index. Analyzing and comparing data of different indexes (see Table 2) differences of country results appear. In the table are presented 3 more countries with purpose to show leading representative of EU in the world rankings by one or another index. Evaluating EPI - such leader is Netherlands, while for NRI rankings, lowest position holds Bulgaria, highest -Finland (which was not analysed in previous research, but presented in Table 2 for common evaluation), in case of GDI the France are in $4^{\text {th }}$ position and Netherlands stands next to with $5^{\text {th }}$ position. Overall it could be concluded that Netherlands are most advanced in e-government infrastructure, communication with citizens in e-space and providing wide range of public e-services (and the evaluation of country is quite stable in terms of all different index rankings). At the same time from analysed countries most advanced in egovernment services are United Kingdom and after words Sweden. Lithuania in this analysis present itself as one of stabile and in all areas equally developed country with a rank of $(33,31,29)$. So, for citizens and for foreigners (including migrants) the e-government services together with e-infrastructure for creating businesses and solving selfemployment issues most attractive are Netherlands, France, Finland, United Kingdom, and Sweden. Despite that in some countries such as Denmark, Norway, Italy, Austria holds quite high results and are ICT developed high-income countries. According the indexing most challenging to establish business distantly or e-business would be Bulgaria.

Table 2. Comparison of specific European countries by EPI, NRI, and GDI (Source: compiled by authors using The Dutta et al. (2015), UNPAN (2014))

\begin{tabular}{|c|c|c|c|c|c|c|}
\hline $\begin{array}{l}\stackrel{\Xi}{\Xi} \\
\text { 它 }\end{array}$ & $\begin{array}{l}\underset{\mathbf{a}}{I} \\
\underset{\sim}{ \pm} \\
\stackrel{\sim}{\mathbf{d}}\end{array}$ & 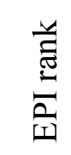 & $\frac{\vec{z}}{z}$ & 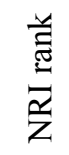 & $\underset{\circlearrowright}{ \pm}$ & $\frac{\underline{\Xi}}{\vec{\Xi}}$ \\
\hline Austria & 0,6275 & 40 & 5,4 & 22 & 0,7912 & 20 \\
\hline Bulgaria & 0,2549 & 124 & 4 & 73 & $\mathrm{n} / \mathrm{d}$ & $\mathrm{n} / \mathrm{d}$ \\
\hline Cyprus & 0,3137 & 107 & 4,7 & 37 & $\mathrm{n} / \mathrm{d}$ & $\mathrm{n} / \mathrm{d}$ \\
\hline $\begin{array}{l}\text { Czech } \\
\text { Republic }\end{array}$ & 0,2549 & 122 & 4,5 & 42 & $\mathrm{n} / \mathrm{d}$ & $\mathrm{n} / \mathrm{d}$ \\
\hline Denmark & 0,5490 & 54 & 5,5 & 13 & 0,8162 & 16 \\
\hline Italy & 0,7843 & 19 & 4,3 & 58 & 0,7592 & 23 \\
\hline Lithuania & 0,6471 & 33 & 4,9 & 31 & 0,7271 & 29 \\
\hline Norway & 0,6863 & 30 & 5,8 & 5 & 0,8357 & 13 \\
\hline Portugal & 0,6471 & 33 & 4,9 & 33 & $\mathrm{n} / \mathrm{d}$ & $\mathrm{n} / \mathrm{d}$ \\
\hline Slovenia & 0,3922 & 84 & 4,6 & 36 & $\mathrm{n} / \mathrm{d}$ & $\mathrm{n} / \mathrm{d}$ \\
\hline Sweden & 0,6078 & 45 & 5,8 & 3 & 0,8225 & 14 \\
\hline $\begin{array}{l}\text { United } \\
\text { Kingdom }\end{array}$ & 0,9608 & 4 & 5,6 & 9 & 0,8695 & 8 \\
\hline Finland & 0,7059 & 24 & 6,0 & 1 & 0,8449 & 10 \\
\hline France & 0,9608 & 4 & 5,2 & 25 & 0,8938 & 4 \\
\hline $\begin{array}{l}\text { Nether- } \\
\text { lands }\end{array}$ & 1,0000 & 1 & 5,8 & 4 & 0,8897 & 5 \\
\hline
\end{tabular}

\section{Conclusions}

Although the importance of migrant entrepreneurship for Europe is recognized by many scholars and policy makers and there is a remarkable literature on this topic, the data and information on migrant entrepreneurship are not comparable and are limited especially at the EU level. Most studies address a specific migrant group in a city (e.g. migrants in Thessaloniki, or Turkish entrepreneurs in Swiss cities). And there is a gap in evaluating migrant entrepreneurship. 

Question "Which European country is the migrant-friendliest one according establishing of enterprises by migrant self-employed people?" is undiscovered by previous research. As the literature showed, several personal in-depth interviews via telephone (e.g. case in Switzerland) and via faceto-face (e.g. case in Greece) were done. In best case all researchers that are interested in migrant entrepreneurship can work at the survey construction, implementation and interpretation.

Suggestions for political decisions can be supported and migrant interested people can easily identify the most convenient country for their business ideas. While a uniform policy that would be applicable in all European countries is not attainable it is still possible to draw some more general conclusions which - with modifications and adaptations - should be useful to consider for policy makers throughout Europe. Migrant and ethnic minority entrepreneurship cannot be understood in terms of nationality and ethnicity alone. Important factors are also the size and location (ethnic clusters) of the ethnic group and the duration that an ethnic group has stayed in the new country. The level of education, qualifications and IT use competences also shape business opportunities, so good ICT practice of successful member countries should be followed and applied by thus who having low EPI, GDI, NRI ranks.

\section{References}

Aldrich, H.; Waldinger, R. 1990. Migrantity and entrepreneurship, Annual Review of Sociology 16: 111-135.

http://dx.doi.org/10.1146/annurev.so.16.080190.000551

Aldrich, H.; Zimmer, C. 1986. Entrepreneurship through social networks, in D. Sexton and R. Wilson (Eds.). The art and science of entrepreneurship. Cambridge: Ballinger Publishing, 154167.

Anyadike-Danes, M.; Harding, R.; Hart, M.; Levie, J. 2007. Migrant and non-migrant entrepreneurhsip in the United Kingdom: Individual, local and regional effects on quantity and quality, Frontiers of Entrepreneurship Research 27(9).

Baumol, W. J. 1968. Entrepreneurship in economic theory, American Economic Review: 58(2): 64-71 [online], [cited 12 December 2015]. Available from Internet: http://www.jstor.org/stable/1831798

Baycan, T.; Nijkamp, P.; Sahin, M. 2008. The economic imporatnce of migrant entrepreneurhsip: An application of data envelopment analysis in the Netherlands. Research Memorandum, VRIJE Universiteit Amsterdam.
Baycan-Levent, T.; Kundak, S. 2009. Motivation and driving forces of Turkish entrepreneurs in Switzerland, Innovation: The European Journal of Social Science Research 22(3): 283-308. http://dx.doi.org/10.1080/13511610903383710

Baycan-Levent, T.; Masurel, E.; Nijkamp, P. 2003. Diversity in entrepreneurship: migrant and female roles in urban economic life, International Journal of Social Economics 30: 1131-1161. http://dx.doi.org/10.1108/03068290310497495

Baycan-Levent, T.; Nijkamp, P. 2005. Determinants of migrant entrepreneurship in Europe, in $45^{\text {th }}$ Congress of the European Regional Science Association, 23-27 August 2005, Amsterdam, the Netherlands.

Baycan-Levent, T.; Nijkamp, P. 2007. Migrant entrepreneurship in a diverse Europe: In search of sustainable development. Serie Research Memoranda from VU University Amsterdam, Faculty of Economics [online], [cited 12.12.2015]. Available from Internet:

http://EconPapers.repec.org/RePEc:vua:wpaper:2007-11

Baycan-Levent, T.; Nijkamp, P. 2009. Characteristics of migrant entrepreneurship in Europe, Entrepreneurship and Regional Development 21(4): 375-397. http://dx.doi.org/10.1080/08985620903020060

Baycan-Levent, T.; Sahin, M.; Peter, N. 2007. Multicultural diversity and migrant entrepreneurship: The case of the Netherlands, ITU 4(1): 20-44.

Butler, J.; Greene, P. 1997. Ethnic entrepreneurship: the continuous rebirth of American entrepreneurship, in D. Sexton, R. Smilor (Eds). Entrepreneurship. Chicago: IL: Upstart Publishing, 267-289.

Chaganti, R.; Greene, P. 2002. Who are ethnic entrepreneurs? A study of entrepreneurs' ethnic involvement and business characteristics, Journal of Small Business Management 40(2): 126-143. http://dx.doi.org/10.1111/1540-627X.00045

Davidsson, P. 2003. The domain of entrepreneurship research: some suggestions, in J. Katz, A. Corbett (Eds.). Advances in entrepreneurship, firm emergence and growth 6: 2-90. http://dx.doi.org/10.1016/S1074-7540(03)06010-0

Desiderio, M. V. 2014. Policies to support immigrant entrepreneurship: A project of the Migration Policy Institute. Washington DC: Transatlantic Council on Migration.

Dutta, S.; Geiger, T.; Lanvin, B. (Eds.) 2015. Global Information Technology Report 2015. ICTs for Inclusive Growth. Geneva: World Economic Forum and INSEAD [online], [cited 12 December 2015]. Available from Internet: http://www3.weforum.org/docs/WEF_Global_IT_ Report_2015.pdf

Eckhardt, J.; Shane, S. 2003a. The individualopportunity nexus, in J. Zoltan, D. B. Audretsch (Eds). Handbook of entrepreneurship research: an 
interdisciplinary survey and introduction. $2^{\text {nd }}$ ed. Boston: Springer, 181-194. http://dx.doi.org/10.1016/S0149-2063(02)00225-8

Eckhardt, J.; Shane, S. 2003b. Opportunities and entrepreneurship, Journal of Management 29(3): 333-349.

European Commission. 2008. Supporting entrepreneurial, ethnic minority entrepreneurship/migrant entrepreneurship, conclusions and recommendations. Ref. Ares(2014)76602 - 15/01/2014, Brussels, European Commission.

European Commission. 2012. Entrepreneurship determinants: culture and capabilities. Luxembourg: Publications Office of the European Union.

Gartner, W. B. 1990. What are we talking about when we talk about entrepreneurship?, Journal of Business Venturing 5(1): 15-28. http://dx.doi.org/10.1016/0883-9026(90)90023-M

Hatziprokopiou, P. 2008. Migrant entrepreneurs in Greece, OLIVEIRA: Migracoes Journal - Special Issue on Immigrant Entrepreneurship, 73-84.

Hatziprokopiou, P.; Labrianidis, L. 2010. Migrant entrepreneurship in Greece: diversity of pathways for emerging ethnic business communities in Thessaloniki, Journal of International Migration and Integration 11(2): 193-217.

http://dx.doi.org/10.1007/s12134-010-0134-8

Kloosterman, R. 2010. Matching opportunities with resources: A framework for analysing (migrant) entrepreneurship from a mixed embeddedness perspective, Entrepreneurship and Regional Development 22(1): 25-45. http://dx.doi.org/10.1080/08985620903220488

Kloosterman, R.; van der Leun, J.; Rath, J. 2002. Mixed embeddedness: (in)formal economic activities and immigrant business in Netherlands, International Journal of Urban and Regional Research 26(3): 252-266.

Liargovas, P.; Skandalis, K. 2012. Motivations of migrant entrepreneurship in Greece: a factor analysis approach, Journal of Small Business and Enterprise Development 19(4): 627-639.

http://dx.doi.org/10.1108/14626001211277433

Light, I. 1972. Ethnic enterprises in America. Berkeley: University of California Press.

Masurel, E.; Nijkamp, P.; Vindigni, G. 2004. Breeding places for ethnic entrepreneurs: a comparative marketing approach, Entrepreneurship and Regional Development, 16(2): 77-86. http://dx.doi.org/10.1080/0898562042000205045

Mingione, E. 2002. Introduction: immigrants and the informal economy in European cities, International Journal of Urban and Regional Research 26(3): 209-311. http://dx.doi.org/10.4324/9780203361726.bmatt

OECD. 2006. International migration outlook. Annual Report, SOPEMI. Paris: Organisation for economic co-operation and development (OECD).
Peneder, M. 2009. The meaning of entrepreneurship: a modular concept, Journal of Industry, Competition and Trade 9(2): 77-99.

http://dx.doi.org/10.1007/s10842-009-0052-7

Quassoli, F. 2002. Migrants in the Italian underground economy, International Journal of Urban and Regional Research 26(3): 212-231.

Rumelt, R. 1987. Theory, strategy, and entrepreneurship, in D. Teece (Ed.). The competitive challenge: strategies for industrial innovation and renewal. Cambridge: Ballinger Publishing, 137-158.

Rusinovic, K. 2008. Moving between markets? Immigrant entrepreneurs in different markets, International Journal of Entrepreneurial Behavior and Research 14(6): 440-454. http://dx.doi.org/10.1108/13552550810910997

Schmiemann, M. 2012. Entrepreneurship determinants: culture and capabilities. Eurostat: statistical books. Luxembourg: Publication Office of the European Union.

Simon, G. 1993. Immigrant entrepreneurs in France. London: Transaction Publishers.

Stalker, P. 2002. Migration trends and migration policy in Europe, International Migration 40(5): 151179. http://dx.doi.org/10.1111/1468-2435.00215

UNPAN. 2014. UN e-Government Survey 2014. EGovernment for the Future We Want. New York: UNPAN [online], [cited 12 December 2015]. Available from Internet: http:/unpan3.un.org/ egovkb/Portals/egovkb/Documents/un/2014Survey/E-Gov_Complete_Survey-2014.pdf

US Department of Commerce. 1997. The state of small business: a report of the President. Washington DC: Government Printing Office.

Venkataraman, S. 1997. The distinctive domain of entrepreneurship research, in J. A. Katz (Ed.). Advances in Entrepreneurship, Firm Emergence and Growth 3: 119-138 [online], [cited 12 December 2015]. Available from Internet: https://www.researchgate.net/publication/2283163 84_The_Distinctive_Domain_of_Entrepreneurship Research (pp.)

Verheul, I.; Wennekers, S.; Audretsch, D.; Thurik, R. 2001. An eclectic theory of entrepreneurship: policies, institutions and culture, Research Report 0012. Zoetermeer: EIM.

Waldinger, R.; Aldrich, H.; Ward, R. 1990. Ethnic entrepreneurs. Newbury Park: Sage Publishers.

Ward, R.; Jenkis, R. 1984. Ethnic communities in business. Cambridge: Cambridge University Press.

Wauters, B.; Lambrecht, J. 2008. Barriers to refugee entrepreneurship in Belgium: towards an explanatory model, Journal of Ethnic and Migration Studies 34(6): 895-915. http://dx.doi.org/10.1080/13691830802211190 